\title{
Selenium from beef is highly bioavailable as assessed by liver glutathione peroxidase $(E C$ 1.11.1.9) activity and tissue selenium*
}

\author{
BY BING SHI AND JULIAN E. SPALLHOLZ† \\ Food and Nutrition, Texas Tech University, Lubbock, Texas 79409, USA
}

(Received 12 November 1993 - Revised 11 March 1994 - Accepted 12 April 1994)

\begin{abstract}
The bioavailability of Se from ground beef has been previously found in this laboratory to be greater than that of selenite or selenate when fed to female Fischer 344 rats. In the present study we examined the bioavailability of Se from various commercial portions of beef, the liver, striploin, round, shoulder and brisket. All beef was cooked, freeze-dried, finely powdered and mixed with the other dietary ingredients. The experimental diets were fed to the weanling Fischer 344 rats which had been subjected to dietary depletion of Se for 6 weeks. The bioavailability of Se from the beef diets was compared with that of Se as selenite or L-selenomethionine (SeMet) added to torula-yeast diets. Each experimental diet contained $0 \cdot 10 \mathrm{mg} \mathrm{Se} / \mathrm{kg}$. After 8 weeks of dietary Se repletion, relative activity of liver glutathione peroxidase (EC 1.11.1.9; GSHPx) from the different dietary groups compared with that of control animals $(100 \%)$ was $(\%)$ : selenite 91 , SeMet $122(P<0.05)$, liver 108, striploin 105, round 106, shoulder 106, brisket 103. Se recovery for liver GSHPx was generally highest from SeMet $>$ beef muscle $=$ beef liver $>$ selenite. Muscle tissue deposition of Se was highest from SeMet $>$ beef muscle $>$ selenite $=$ beef liver. In addition, the faecal excretion of Se was lowest from the SeMet dietary group and highest from the selenite dietary group. The experimental results suggest that all cuts of beef appear to be highly bioavailable sources of dietary Se when compared with selenite or L-SeMet.
\end{abstract}

Selenium bioavailability: Beef: Selenite: Selenomethionine

Se for people in the United States is mainly supplied by cereals, breads, meats and meat products (Schubert et al. 1987). Beef alone is estimated to contribute approximately 17\% of the total Se in the American diet (Holden et al. 1991).

The reported bioavailability of Se from foods varies considerably, ranging from 9 (dried fish solids) to $210 \%$ (dehydrated lucerne (Medicago sativa) meal) when compared with $\mathrm{Na}_{2} \mathrm{SeO}_{3}$ (selenite; $100 \%$ ) in chickens (Cantor et al. 1981). In general, the bioavailability of Se from foods of plant origin is comparable with or somewhat greater than that of $\mathrm{Na}_{2} \mathrm{SeO}_{3}$. Se from foods of animal origin is generally less bioavailable (Combs \& Combs, 1986). Such experimental conclusions have been based mainly on data from fish, chicken and meats other than beef in comparison with selenite and selenomethionine (SeMet; Douglass et al. 1981; Alexander et al. 1983; Bell \& Cowey, 1989).

The bioavailability of Se from both raw and cooked ground beef has been previously found in this laboratory to be greater than that of $\mathrm{Na}_{2} \mathrm{SeO}_{3}$ or $\mathrm{Na}_{2} \mathrm{SeO}_{4}$ (selenate), as measured by recovery of liver glutathione peroxidase (EC 1.11.1.9; GSHPx) activity as well as by the total Se content deposited in liver and muscle of rats (Shi \& Spallholz, 1994). In the present study we examined the bioavailability of Se from various portions of fully cooked commercial cuts of beef, including liver, striploin, round, shoulder and brisket. The

* A preliminary report of this research was presented at the 1993 Federation of American Societies for Experimental Biology Meeting in New Orleans, LA, USA: Shi, B. \& Spallholz, J. E. (1993). The bioavailability of selenium from beef assessed in Fischer 344 rats. FASEB Journal 5, A290.

$\dagger$ For reprints. 
bioavailability of Se from beef was compared with the bioavailability of Se from $\mathrm{Na}_{2} \mathrm{SeO}_{3}$ and L-SeMet in recovery experiments using weanling Fischer 344 rats.

\section{MATERIALS AND METHODS}

\section{Animals}

Female weanling Fischer 344 rats (n 210; Sasco/King Animal Laboratory, Omaha, NE, USA) were individually housed in suspended stainless-steel-wire cages in a temperaturecontrolled $\left(21-24^{\circ}\right)$ room with a $12 \mathrm{~h}$ light-dark cycle. Animals had free access to distilled water and diets.

\section{Diets}

A torula-yeast (TY) basal diet (Table 1) was used in this experiment. Various commercial portions of beef: the liver, striploin (loin), round, shoulder and brisket (from the ExCel Packing Plant, Plainview, TX, USA) were cooked well-done (approximately $3 \mathrm{~h}$ at $180^{\circ}$ in a conventional General Electric home oven). They were then cut into small pieces, freezedried in a freeze-dryer (Labconco, Kansas City, MO, USA) for $24 \mathrm{~h}$, finely powdered using a Waring blender, and analysed for their Se (Spallholz et al. 1978), crude fat, protein and moisture contents (Horwitz, 1970). To the TY basal diet was added $0 \cdot 10 \mathrm{mg} / \mathrm{kg}$ of Se as $\mathrm{Na}_{2} \mathrm{SeO}_{3}, \mathrm{~L}-\mathrm{SeMet}$, or Se as beef (Table 1). The fat and protein contents of all diets were adjusted to similar levels by adding or withholding beef tallow (fat), torula yeast (protein) or sucrose from the diets. The final mixed TY and beef diets were then assayed for their Se, crude fat and protein contents (Table 2). Food consumption for each dietary group of rats was measured throughout the 8-week repletion period.

\section{Experimental design}

The entire experiment lasted 14 weeks with two distinguishable periods. The Se-depletion and Se-repletion periods consisted of 6 and 8 weeks respectively. For the first 6 weeks (Sedepletion period) the animals were divided into two dietary groups. Thirty animals were fed on the TY diet to which had been added $0.10 \mathrm{mg} \mathrm{Se}$ as $\mathrm{Na}_{2} \mathrm{SeO}_{3} / \mathrm{kg}$ (control group). The remaining animals were all fed on the TY basal diet which contained 0.008 (SD 0.0002) $\mathrm{mg}$ $\mathrm{Se} / \mathrm{kg}$ (Se-deficient group). At the end of the 6-week depletion period six animals from each of the two groups were killed and tissues (liver and muscle) were removed for Se bioassays. From week 7 to week 14 (repletion period) the animals were divided into eight dietary groups. Each separate diet contained about $0.10 \mathrm{mg} \mathrm{Se}$ as $\mathrm{Na}_{2} \mathrm{SeO}_{3} / \mathrm{kg}$ (Table 2), SeMet, beef liver, striploin, round, shoulder or brisket. Six animals from each of the eight dietary groups were killed at weeks 1, 2, 4 and 8 of the repletion period. Liver and muscle tissues obtained from each animal were then assayed for their total Se content. Liver tissue was analysed for GSHPx activity.

\section{Selenium bioassays}

The rats were weighed and killed by cervical dislocation. Liver (medulla lobe) and muscle (left posterior leg) tissues were excised, washed in cold saline $(9 \mathrm{~g} \mathrm{NaCl} / 1)$, blotted, weighed and stored at $+4^{\circ}$. Within $12 \mathrm{~h}$ liver tissues were homogenized in 3 vol. of cold sucrose solution $(0.25 \mathrm{~mol} / \mathrm{l})$ using a Potter-Elvehjem mortar and pestle and were centrifuged using a Beckman J-21 ultracentrifuge (Palo Alto, CA, USA) for $20 \mathrm{~min}$ at $35000 \mathrm{~g}$ at $+4^{\circ}$. The tissue supernatant fractions were collected and kept frozen at $-75^{\circ}$ until assayed for the Se-dependent GSHPx and protein. GSHPx activity was assayed by a modification of the method of Paglia \& Valentine (1967) using a u.v.-visible model UV-160 spectrophotometer (Shimadzu, Kyoto, Japan) by monitoring the oxidation of NADPH at $340 \mathrm{~nm}$. Our modified cocktail mixture contained (mmol/l): glutathione 2, NADPH 0.15, glutathione reductase (EC 1.6.4.2) 1 unit, $\mathrm{NaN}_{3}$ 1, potassium phosphate buffer (pH 7.0) 50 and EDTA 1.5. 
Table 1. Composition of experimental diets $(\mathrm{g} / \mathrm{kg})$

\begin{tabular}{lcccccc}
\hline & & \multicolumn{5}{c}{ Beef diets } \\
\cline { 3 - 7 } Ingredients & TY diet* & Liver & Striploin & Round & Shoulder & Brisket \\
\hline Torula yeast & 200 & 155 & 104 & 91 & 86 & 43 \\
Beef & 0.0 & 45 & 127 & 125 & 143 & 208 \\
Sucrose & 645 & 645 & 645 & 645 & 645 & 634 \\
Beef tallow & 40 & 40 & 9 & 24 & 11 & 0.0 \\
Maize oil & 10 & 10 & 10 & 10 & 10 & 10 \\
Others $\dagger$ & 155 & 155 & 155 & 155 & 155 & 155 \\
\hline \hline
\end{tabular}

* Protein source is torula yeast.

$\dagger$ All diets contained the same amounts of the following five components $(\mathrm{g} / \mathrm{kg})$ : AIN Mineral Mixture 76 omitting Se 40, AIN Vitamin Mixture 76 10, cellulose 50, choline bitartrate 0.2, DL-methionine 0.3. All these five chemicals were purchased from the United State Biochemical Corporation, Cleveland, OH, USA.

Table 2. Selenium, crude fat and protein concentrations, energy and moisture in experimental diets*

(Mean values and standard deviations for four samples)

\begin{tabular}{|c|c|c|c|c|c|c|}
\hline \multirow[b]{2}{*}{ Diets } & \multicolumn{2}{|c|}{$\begin{array}{c}\text { Sef } \\
(\mathrm{mg} / \mathrm{kg})\end{array}$} & \multirow{2}{*}{$\begin{array}{c}\text { Fat }{ }_{+}^{+} \\
(\mathrm{g} / \mathbf{k g})\end{array}$} & \multirow{2}{*}{$\begin{array}{c}\text { Protein } \\
\text { (g/kg) }\end{array}$} & \multirow{2}{*}{$\begin{array}{l}\text { Energy\$ } \\
\text { (KJ/kg) }\end{array}$} & \multirow{2}{*}{$\begin{array}{r}\text { Moisture } \\
(\mathrm{g} / \mathrm{kg})\end{array}$} \\
\hline & Mean & SD & & & & \\
\hline Control & $0 \cdot 115$ & 0.020 & 57 & 99 & 14660 & 57 \\
\hline Selenite & 0.115 & 0.020 & 57 & 99 & 14660 & 57 \\
\hline SeMet & $0 \cdot 115$ & $0 \cdot 013$ & 57 & 99 & 14660 & 57 \\
\hline Liver & $0 \cdot 109$ & $0 \cdot 008$ & 63 & 104 & 14950 & 63 \\
\hline Striploin & 0.117 & 0.006 & 56 & 139 & 15290 & 56 \\
\hline Round & $0 \cdot 117$ & $0-011$ & 57 & 142 & 15370 & 57 \\
\hline Shoulder & 0.112 & 0.011 & 55 & 148 & 15410 & 55 \\
\hline Brisket & $0 \cdot 114$ & 0.006 & 68 & 151 & 15750 & 68 \\
\hline
\end{tabular}

SeMet, selenomethionine.

* For details of diets, see Table 1 and p. 874.

$\dagger$ Assayed by the fluorometric method of Spallholz et al. (1978).

\$ Crude fat, protein and moisture contents of diets were measured by the proximate analysis of Horwitz (1970).

$\S$ Calculated by $(\mathrm{g}$ crude fat $\times 37.8)+(\mathrm{g}$ crude protein $(\mathrm{N} \times 6.25) \times 16.8)+(\mathrm{g}$ sucrose $\times 16.8)$.

$\mathrm{H}_{2} \mathrm{O}_{2}(0 \cdot 25 \mathrm{mmol} / \mathrm{l})$ was used as the substrate for GSHPx. The protein content of the tissue homogenates was determined by a commercial protein assay (Bio-Rad Laboratories, Richmond, CA, USA; Simpson \& Sonne, 1982). Protein standards were prepared from bovine serum albumin (Sigma, St Louis, MO, USA). About $100 \mathrm{mg}$ liver tissue, $300 \mathrm{mg}$ muscle and $150 \mathrm{mg}$ faeces were collected from each animal for total Se concentration analysis by the fluorometric method described by Spallholz et al. (1978) using a fluorescence spectrophotometer (model 650-40; Perkin-Elmer, Norwalk, CT, USA). Standard curves were prepared using $\mathrm{Na}_{2} \mathrm{SeO}_{3}$.

\section{Statistical analysis}

All values are given as the mean values and standard deviation. Statistical differences between means were determined by one-way ANOVA and the level of significance was set at $P<0.05$. 
Table 3. Liver glutathione peroxidase (EC 1.11.1.9; GSHPx; $\mathrm{mU} / \mathrm{min}$ per $\mathrm{mg}$ protein) activity of rats during the selenium-depletion and Se-repletion periods*

(Mean values and standard deviations for six animals)

\begin{tabular}{|c|c|c|c|c|c|c|c|c|c|c|c|c|}
\hline \multirow{3}{*}{$\begin{array}{l}\text { Treatment } \\
\text { group }\end{array}$} & \multicolumn{4}{|c|}{ Period of depletion (weeks) } & & & \multicolumn{4}{|c|}{ Period of repletion (weeks) } & & \\
\hline & \multicolumn{2}{|c|}{0} & \multicolumn{2}{|c|}{6} & \multicolumn{2}{|c|}{1} & \multicolumn{2}{|c|}{2} & \multicolumn{2}{|c|}{4} & \multicolumn{2}{|c|}{8} \\
\hline & Mean & SD & Mean & SD & Mean & SD & Mean & SD & Mean & SD & Mean & SD \\
\hline $\begin{array}{l}\text { Control } \\
\text { Se-deficient }\end{array}$ & 333 & $51 \dagger$ & $\begin{array}{r}726^{\mathrm{a}} \\
14^{\mathrm{b}}\end{array}$ & $\begin{array}{r}44_{+}^{+} \\
28\end{array}$ & $866^{a}$ & 70 & $665^{\mathrm{a}}$ & 51 & $669^{\mathrm{a}}$ & 67 & $669^{\mathrm{bc}}$ & 24 \\
\hline Selenite & & & & & $135^{\mathrm{c}}$ & 33 & $294^{\mathrm{ef}}$ & 45 & $573^{\mathrm{b}}$ & 42 & $608^{\mathrm{c}}$ & 32 \\
\hline SeMet & & & & & $233^{b}$ & 22 & $542^{\mathrm{b}}$ & 44 & $714^{\mathrm{a}}$ & 61 & $817^{\mathrm{a}}$ & 36 \\
\hline Liver & & & & & $115^{\mathrm{c}}$ & 19 & $304^{\text {de }}$ & 27 & $595^{\mathrm{b}}$ & 71 & $723^{b}$ & 90 \\
\hline Striploin & & & & & $96^{\mathrm{c}}$ & 16 & $258^{p}$ & 19 & $564^{\mathrm{b}}$ & 53 & $703^{b}$ & 71 \\
\hline Round & & & & & $108^{\mathrm{c}}$ & 17 & $362^{\mathrm{c}}$ & 22 & $584^{\mathrm{b}}$ & 22 & $706^{b}$ & 49 \\
\hline Shoulder & & & & & $112^{\mathrm{c}}$ & 16 & $342^{\mathrm{cd}}$ & 34 & $601^{b}$ & 19 & $710^{\mathrm{b}}$ & 91 \\
\hline Brisket & & & & & $96^{\mathrm{e}}$ & 14 & $296^{\mathrm{ef}}$ & 38 & $551^{b}$ & 25 & $691^{\mathrm{b}}$ & 80 \\
\hline
\end{tabular}

$\mathbf{a}, \mathbf{b}, \mathbf{c}, \mathbf{d}, \mathbf{e}, \mathbf{f}$ Mean values in a column with different superscript letters were significantly different (one-way

ANOVA; $P<0.05)$.

SeMet, selenomethionine.

* For details of diets and treatments, see Table 1 and p. 876.

+ Value from six animals fed on a normal rodent diet on arrival.

\$ Value from six animals fed on a Se-adequate (control) torula-yeast diet for 6 weeks.

$\S$ Value from six animals fed on a Se-deficient diet for 6 weeks.

\section{RESULTS}

Feed consumption and body weights of rats

Feed consumption among all dietary groups of rats was similar during the repletion period. No significant differences in the body weights between groups of rats were observed at the end of the experimental period. Rats fed on the beef diets were no more than $5.5 \%$ heavier than the animals fed on the TY diets during the entire Se-repletion period.

\section{Liver glutathione peroxidase activity}

Weanling rats fed on the Se-deficient TY basal diet for 6 weeks had only $1.9 \%$ of the liver GSHPx activity of the control animals arbitrarily set at $100 \%$ activity. During the Serepletion period liver GSHPx activity recovered rapidly with the highest recovery occurring in the dietary SeMet group of animals. The rats fed on selenite had a recovery of GSHPX activity similar to the rats fed on beef during the first 4 weeks of the repletion period. These selenite-fed animals showed a significantly lower GSHPx activity than all beef dietary groups by week 8 of the repletion period $(P<0.05$, Table 3$)$.

\section{Selenium deposition in tissues}

At 6 weeks, Se-deficient rats had only $11 \%$ Se in the liver and $47 \%$ Se in muscle tissue compared with control animals whose Se tissue concentrations were arbitrarily set at $100 \%$. During the Se-repletion period both liver and muscle tissues recovered their Se concentration. The SeMet group recovered their Se deposition in liver and muscle tissues faster than any other dietary group. The recovery of liver Se among the beef dietary groups and the selenite group was similar. All beef-muscle dietary groups of rats had a slightly higher muscle Se concentration than the beef-liver dietary group and the selenite group (Tables 4, 5). Muscle Se in animals fed on the liver diet was only $90 \%$ of the control by the 
Table 4. Total liver selenium concentration (ng/g wet weight) of rats during the Sedepletion and Se-repletion periods*

(Mean values and standard deviations for six animals)

\begin{tabular}{|c|c|c|c|c|c|c|c|c|c|c|c|c|}
\hline \multirow{3}{*}{$\begin{array}{l}\text { Treatment } \\
\text { group }\end{array}$} & \multicolumn{4}{|c|}{ Period of depletion (weeks) } & \multicolumn{8}{|c|}{ Period of repletion (weeks) } \\
\hline & \multicolumn{2}{|c|}{0} & \multicolumn{2}{|c|}{6} & \multicolumn{2}{|l|}{1} & \multicolumn{2}{|c|}{2} & \multicolumn{2}{|c|}{4} & \multicolumn{2}{|c|}{8} \\
\hline & Mean & SD & Mean & SD & Mean & SD & Mean & SD & Mean & SD & Mean & SD \\
\hline $\begin{array}{l}\text { Control } \\
\text { Se-deficient }\end{array}$ & 1054 & $192 \dagger$ & $\begin{array}{l}936^{\mathrm{a}} \\
107^{\mathrm{b}}\end{array}$ & $\begin{array}{r}195 \ddagger \\
12 \S\end{array}$ & $1084^{a}$ & 232 & $1010^{\mathrm{a}}$ & 100 & $1064^{a}$ & 141 & $1006^{c}$ & 105 \\
\hline Selenite & & & & & $204^{\mathrm{d}}$ & 86 & $558^{\mathrm{e}}$ & 19 & $930^{\mathrm{a}}$ & 93 & $1059^{\mathrm{bc}}$ & 60 \\
\hline SeMet & & & & & $532^{\mathrm{b}}$ & 74 & $926^{\mathrm{b}}$ & 76 & $1069^{\mathrm{a}}$ & 60 & $1229^{\mathrm{a}}$ & 129 \\
\hline Liver & & & & & $332^{c}$ & 36 & $516^{\mathrm{a}}$ & 80 & $942^{\mathrm{n}}$ & 77 & $1029^{\mathrm{be}}$ & 132 \\
\hline Striploin & & & & & $343^{\mathrm{c}}$ & 25 & $617^{\mathrm{d}}$ & 34 & $965^{\mathrm{a}}$ & 116 & $1063^{b c}$ & 112 \\
\hline Round & & & & & $372^{\mathrm{c}}$ & 22 & $732^{\mathrm{c}}$ & 29 & $1027^{a}$ & 80 & $1114^{\mathrm{abc}}$ & 46 \\
\hline Shoulder & & & & & $361^{\mathrm{c}}$ & 30 & $575^{\mathrm{de}}$ & 53 & $956^{\mathrm{a}}$ & 28 & $1176^{\mathrm{ab}}$ & 145 \\
\hline Brisket & & & & & $317^{e}$ & 38 & $545^{\mathrm{de}}$ & 59 & $995^{\mathrm{a}}$ & 176 & $1009^{c}$ & 162 \\
\hline
\end{tabular}

a,b.c.d, e Mean values in a column with different superscript letters were significantly different (one-way ANOVA; $P<0-05$ ).

SeMet, selenomethionine.

* For details of diets and treatments, see Table 1 and p. 876.

$\dagger$ Value from six animals fed on a normal rodent diet on arrival.

¥ Value from six animals fed on a Se-adequate (control) torula-yeast diet for 6 weeks.

$\S$ Value from six animals fed on a Se-deficient diet for 6 weeks.

Table 5. Total muscle selenium concentration (ng/g wet weight) of rats during the Sedepletion and Se-repletion periods*

(Mean values and standard deviations for six animals)

\begin{tabular}{|c|c|c|c|c|c|c|c|c|c|c|c|c|}
\hline \multirow{3}{*}{$\begin{array}{l}\text { Treatment } \\
\text { group }\end{array}$} & \multicolumn{4}{|c|}{ Period of depletion (weeks) } & \multicolumn{8}{|c|}{ Period of repletion (weeks) } \\
\hline & \multicolumn{2}{|c|}{0} & \multicolumn{2}{|c|}{6} & \multicolumn{2}{|c|}{1} & \multicolumn{2}{|c|}{2} & \multicolumn{2}{|c|}{4} & \multicolumn{2}{|c|}{8} \\
\hline & Mean & SD & Mean & SD & Mean & SD & Mean & SD & Mean & SD & Mean & SD \\
\hline $\begin{array}{l}\text { Control } \\
\text { Se-deficient }\end{array}$ & 125 & $24 \dagger$ & $\begin{array}{r}109^{\mathrm{a}} \\
51^{\mathrm{b}}\end{array}$ & $\begin{array}{r}10 \dagger \\
7 \dagger\end{array}$ & $117^{\mathrm{a}}$ & 10 & $112^{\mathrm{a}}$ & 8 & $105^{a}$ & 11 & $109^{c}$ & 15 \\
\hline Selenite & & & & & $58^{d}$ & 4 & $58^{e}$ & 6 & $73^{b}$ & 7 & $102^{\mathrm{d}}$ & 15 \\
\hline SeMet & & & & & $72^{b}$ & 3 & $90^{\mathrm{b}}$ & 11 & $117^{\mathrm{a}}$ & 11 & $152^{\mathrm{a}}$ & 16 \\
\hline Liver & & & & & $58^{\mathrm{d}}$ & 5 & $63^{\mathrm{de}}$ & 9 & $81^{\mathrm{b}}$ & 10 & $98^{d}$ & 22 \\
\hline Striploin & & & & & $63^{\mathrm{cd}}$ & 3 & $77^{\mathrm{c}}$ & 15 & $105^{a}$ & 26 & $118^{\text {bed }}$ & 7 \\
\hline Round & & & & & $60^{\text {ed }}$ & 5 & $77^{\mathrm{e}}$ & 10 & $110^{a}$ & 16 & $125^{\mathrm{be}}$ & 13 \\
\hline Shoulder & & & & & $67^{\mathrm{bc}}$ & 5 & $70^{\mathrm{ed}}$ & 10 & $80^{b}$ & 15 & $137^{\mathrm{ab}}$ & 18 \\
\hline Brisket & & & & & $57^{d}$ & 9 & $71^{\mathrm{ed}}$ & 5 & $83^{\mathrm{ab}}$ & 11 & $115^{\mathrm{ed}}$ & 14 \\
\hline
\end{tabular}

a. b,, ,, e Means in a column with different superscript letters were significantly different (one-way ANOVA; $P<0.05)$.

SeMet, selenomethionine.

* For details of diets and treatments, see Table 1 and p. 876.

$\dagger$ Value from six animals fed on a normal rodent diet on arrival.

$\$$ Value from six animals fed on a Se-adequate (control) TY diet for 6 weeks.

$\S$ Value from six animals fed on a Se-deficient diet for 6 weeks. 


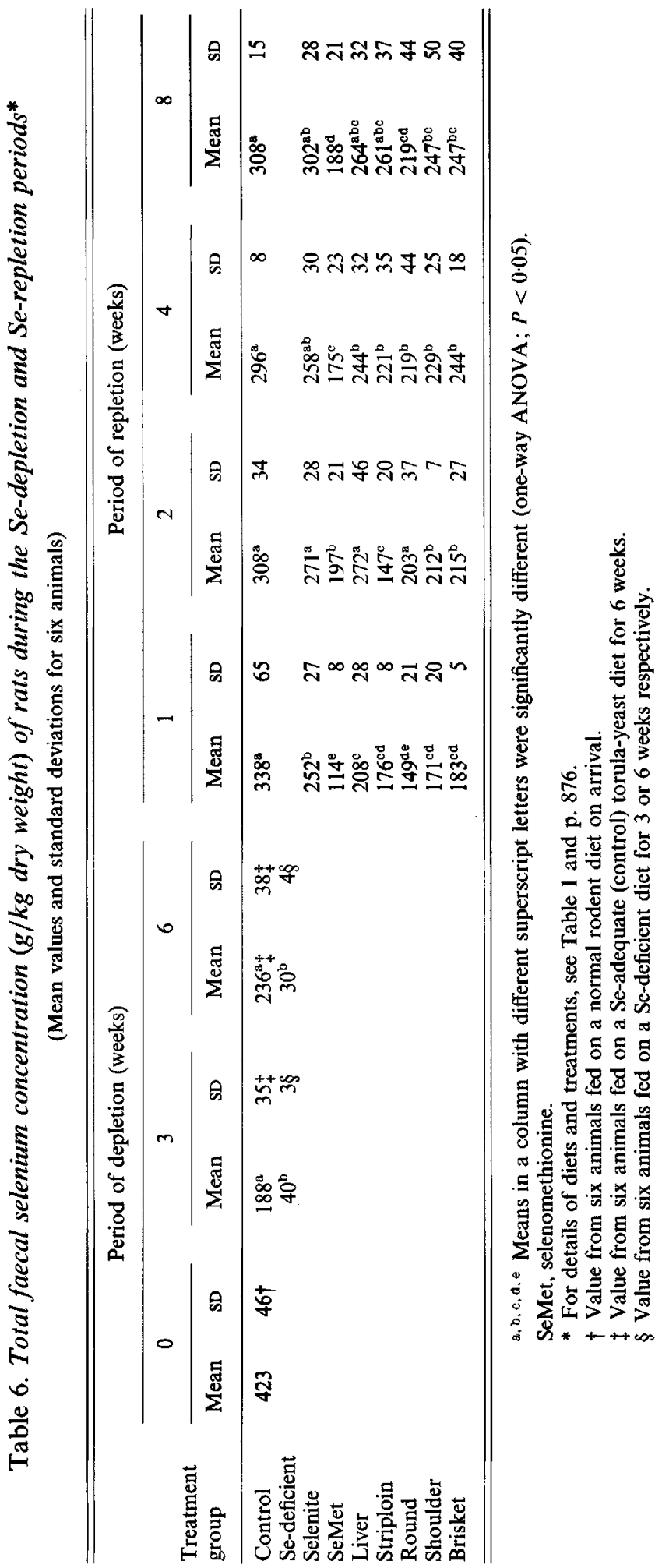


end of the repletion period while all animals fed on beef diets surpassed the control group in the recovery of their muscle Se.

\section{Faecal selenium concentration}

Faecal Se decreased rapidly during the Se-depletion period and increased sharply when dietary Se was resupplemented to rats. Faecal Se levels recovered to control levels within the first 2 weeks of the repletion period in all dietary groups. Faecal Se was lowest in the SeMet-fed animals and highest in the selenite-fed animals. The animals fed on beef liver had the highest level of faecal Se among all dietary groups of rats fed on beef diets (Table 6).

\section{DISCUSSION}

The literature on the bioavailability of Se from animal foods such as fish and meat has generally held the premise that this Se is not as highly bioavailable when compared with equivalent amounts of dietary selenite. Se from plant foods, on the other hand, has been recognized as being more highly bioavailable than Se from animal foods or dietary selenite (Combs \& Combs, 1986).

This laboratory has recently shown that the Se from either raw or cooked ground beef is similar or slightly more bioavailable when compared with dietary selenite fed to Fischer 344 rats (Shi \& Spallholz, 1994). In the present study, conducted in a similar manner to our previous study using raw and cooked ground beef, a comparison was made between the bioavailability of Se from commercial portions of beef and selenite or L-SeMet. L-SeMet was used as a reference source of dietary Se because it is the major dietary form of Se in cereal grains (Osman \& Latshaw, 1976; Sathe et al. 1992). In addition, our previous experience with the ground-beef diets suggested to us that SeMet may be a significant source of dietary Se, not only in cereal grains but also in beef (Shi \& Spallholz, 1994). This inference was gleaned from our previous findings showing that dietary Se repletion in the muscle of Fischer 344 rats was higher from beef diets than from $\mathrm{Na}_{2} \mathrm{SeO}_{3}$.

It is very well known that dietary SeMet will accumulate in muscle tissues to a greater extent than selenite or selenate (Martin \& Hurlbut, 1976; Deagen et al. 1987; Behne et al. 1991). This occurs because SeMet is incorporated into and retained by the primary muscle protein structure replacing methionine whereas dietary selenite and selenate are not retained in the primary protein of muscle (Martin \& Hurlbut, 1976; Deagen et al. 1987; Salbe \& Levander, 1990) nor are these inorganic Se compounds converted to SeMet in animals (Young et al. 1982). Accumulation of Se in muscle tissue is a distinct marker for dietary SeMet occurring in the rat (Osman \& Latshaw, 1976; Behne et al. 1991; Vendeland et al. 1991).

Se bioavailability can be assessed by: (1) the 'functional assay' of GSHPx activity, (2) 'tissue residue level' of Se, or by (3) prevention of a Se-deficiency disease (Combs \& Combs, 1986). Of these three approaches of mineral bioavailability, the third is the least preferred. Because liver GSHPx activity is very sensitive to both Se depletion and Se repletion (Shi \& Spallholz, 1994), and because liver and skeletal muscle comprise the greatest body stores of Se, approximately 30 and $40 \%$ respectively (Behne \& Wolters, 1983), liver GSHPX activity as well as liver and muscle Se concentration were employed as the criteria of the bioavailability of Se in the present study.

Recovery from the depletion of liver GSHPx by rats fed on L-SeMet and beef diets was greater than from the animals fed on selenite at week 8 of the experimental recovery period. Also at week 8, liver GSHPx in comparison with control animals fed on selenite $(100 \%)$ was: SeMet $(122 \%, P<0.05)$, striploin $(105 \%)$, round $(106 \%)$, shoulder $(106 \%)$, brisket 
$(103 \%)$, liver $(108 \%)$ and selenite $(91 \%)$. Thus, all beef diets restored liver GSHPx to recovery values intermediate between those of animals fed on L-SeMet and selenite. GSHPx recovery from depletion of this liver enzyme in rats was the primary means of assessing Se bioavailability (Combs \& Combs, 1986; Greger, 1992).

Total tissue levels of $\mathrm{Se}$ in liver and muscle tissues are secondary measures of bioavailability for dietary Se. Once again, L-SeMet-fed rats recovered more Se both in liver and muscle than the rats fed on the commercial beef diets or the selenite-containing diet. Animals fed on beef-muscle diets recovered their muscle Se more rapidly than animals fed on beef liver and those consuming the selenite diet. The recovery of liver Se showed no significant difference among animals fed on beef diets and those fed on the selenite diet during the later stage (weeks of 4 and 8 ) of the recovery period. We also observed that animals fed on selenite had a higher faecal Se content than those fed on either SeMet or beef Se. Thus, dietary Se absorption constitutes part of the reason for the higher bioavailability of SeMet and beef Se than that of selenite.

The bioavailability of dietary Se is affected not only by its chemical form (Combs \& Combs, 1986) but also by other dietary factors such as the total protein and fat contents of the diet (Osman \& Latshaw, 1976; Zhou et al. 1983; Smith \& Picciano, 1987). The experiment here was designed to be both isoenergetic and nearly isonitrogenous within the experimental limits imposed in formulating $0.10 \mathrm{mg} \mathrm{Se} / \mathrm{kg}$ diets from beef. In addition, animals depleted of Se and repleted with diets containing equal amounts of Se as selenite, L-SeMet or the commercial cooked beef consumed the same amount of diet as provided $a d$ lib. Animals consuming the beef diets were not significantly larger $(P>0.05)$ in body weight than the animals consuming the Se-supplemented TY diets at the end of the repletion period.

Thus, we conclude from our previous study of raw and cooked ground beef (Shi \& Spallholz, 1994) and the present study of the bioavailability of Se from various cuts of commercial beef, that the bioavailability of Se from beef is higher than or at least equal to that of selenite and slightly lower than that of L-SeMet. Our results here are consistent with two recent studies in humans which showed that meat was as good a source of $\mathrm{Se}$, as is wheat (van der Torre et al. 1991), and that SeMet was absorbed more rapidly than selenite in Se-deficient men (Xia et al. 1992).

The authors appreciate and acknowledge the gift of L-selenomethionine from Nutrition 21 , San Diego, CA. Gratefully appreciated is the financial support from the Cattlemen's Beef Promotion Board for the research assistantship to B.S. This research was funded by the Cattlemen's Beef Promotion Board and administered in cooperation with the Beef Industry Council.

\section{REFERENCES}

Alexander, A. R., Whanger, P. D. \& Miller, L. T. (1983). Bioavailability to rats of selenium in various tuna and wheat products. Journal of Nutrition 113, 196-204.

Behne, D., Kyriakopoulos, A., Scheid, S. \& Gessner, H. (1991). Effects of chemical form and dosage on the incorporation of selenium into tissue proteins in rats. Journal of Nutrition 121, 806-814.

Behne, D. \& Wolters, W. (1983). Distribution of selenium and glutathione peroxidase in the rat. Journal of Nutrition 113, 456-461.

Bell, J. G. \& Cowey, C. (1989). Digestibility and bioavailability of dietary selenium from fishmeal, selenomethionine and selenocysteine in Atlantic salmon (Salmo salar). Aquaculture 81, 61-68.

Cantor, A. H., Moorhead, P. D. \& Musser, M. A. (1981). Biological availability of selenium in selenium compounds and feed ingredients. In Selenium in Biology and Medicine, pp. 192-202 [J. E. Spallholz, J. L. Martin and H. E. Ganther, editors]. Westport, Connecticut: AVI Publishing Company.

Combs, G. F. \& Combs, S. B. (editors) (1986). The biological availability of selenium in foods and feeds. In The Role of Selenium in Nutrition, pp. 127-177. New York: Academic Press.

Deagen, J. T., Butler, J. A., Beilstein, M. A. \& Whanger, P. D. (1987). Effects of dietary selenite, selenocysteine 
and selenomethionine on selenocysteine lysase and glutathione peroxidase activities on selenium levels in rat tissues. Journal of Nutrition 117, 91-98.

Douglass, J. S., Morris, V. C., Soares, J. H. Jr \& Levander, O. R. (1981). Nutritional availability to rats of selenium in tuna, beef, kidney, and wheat. Journal of Nutrition 111, 2180-2187.

Greger, J. L. (1992). Using animals to assess bioavailability of minerals: implications for human nutrition. Journal of Nutrition 122, 2047-2052.

Holden, J. M., Gebhardt, S., Davis, C. S. \& Lurie, D. G. (1991). A nationwide study of the selenium contents and variability in white bread. Journal of Food Composition Analysis 4, 183-195.

Horwitz, W. (1970). Official Methods of Analysis of the Association of Official Analytical Chemists. Benjamin Franklin Station, Washington, DC.: AOAC.

Martin, J. L. \& Hurlbut, J. A. (1976). Tissue selenium levels and growth responses of mice fed selenomethionine, Se-methyl selenocysteine or sodium selenite. Phosphorus and Sulfur 1, 295-300.

Osman, M. \& Latshaw, J. F. (1976). Biological potency of selenium from sodium selenite, selenomethionine and selenocysteine in the chick. Poultry Science 55, 987-994.

Paglia, D. E. \& Valentine, W. N. (1967). Studies on the quantitative and qualitative characterization of erythrocyte glutathione peroxidase. Journal of Laboratory and Clinical Medicine 70, 158-168.

Salbe, A. D. \& Levander, O. R. (1990). Comparative toxicity and tissue retention of selenium in methioninedeficient rats fed sodium selenate or L-selenomethionine. Journal of Nutrition 120, 207-212.

Sathe, S. K., Mason, A. C., Rodibaugh, R. \& Weaver, C. M. (1992). Chemical form of selenium in soybean (Glycine max L.) lectin. Journal of Agricultural and Food Chemistry 40, 2084-2091.

Schubert, A., Holder, J. M. \& Walf, W. R. (1987). Selenium content of a core group of foods based on a critical evaluation of published analytical data. Journal of the American Dietetic Association 87, 285-299.

Shi, B. \& Spallholz, J. E. (1994). The bioavailability of selenium from raw and cooked ground beef assessed in selenium deficient Fisher rats. Journal of the American College of Nutrition 13, 95-101.

Simpson, I. A. \& Sonne, O. (1982). A simple, rapid and sensitive method for measuring protein concentration in subecellular membrane fractions prepared by sucrose density ultracentrifugation. Analytical Biochemistry 119 , 424-427.

Smith, A. M. \& Picciano, M. F. (1987). Relative bioavailability of seleno-compounds in the lactating rat. Journal of Nutrition 117, 725-731.

Spallholz, J. E., Collins, G. F. \& Schwarz, K. (1978). A single-test-tube method for the fluorometric microdetermination of selenium. Bioinorganic Chemistry 9, 453-459.

van der Torre, H. W., Van Dokkum, W., Schaafsma, G., Wedel, M. \& Ockhuizen, T. (1991). Effect of various levels of selenium in wheat and meat on blood Se status indices and on Se balance in Dutch men. British Journal of Nutrition 65, 69-80.

Vendeland, S. C., Butler, J. A. \& Whanger, P. D. (1992). Intestinal absorption of selenite, selenate, and selenomethionine in the rat. Journal of Nutritional Biochemistry 3, 359-365.

Xia, Y., Zhao, X., Zhu, L. \& Whanger, P. D. (1992). Metabolism of selenate and selenomethionine by a seleniumdeficient population of men in China. Journal of Nutritional Biochemistry 3, 202-210.

Young, V. R., Nahapetiau, A. \& Janghorbani, M. (1982). Selenium availability with reference to human nutrition. American Journal of Clinical Nutrition 35, 1076-1088.

Zhou, R., Sun, S., Zhai, F., Man, R., Guo, S., Wang, H. \& Yang, G. (1983). Effect of dietary protein level on the availability of selenium. I. Effect of dietary protein level on the selenium contents and glutathione peroxidase activities in blood and tissues of rats. Yingyong Kexue Xuebao 5, 137-142. 